\title{
Occurrence of estrogenic effects in sewage and industrial wastewaters in Beijing, China
}

\author{
Mei Ma, Kaifeng Rao, Zijian Wang* \\ State Key Laboratory of Environmental Aquatic Chemistry, Research Center for Eco-Environmental Sciences, Chinese Academy of Sciences, \\ Beijing 100085, P.R. China
}

Received 29 April 2006; accepted 24 May 2006

Estrogenic activity in Beijing river water is attributed to direct discharges of untreated municipal and industrial wastewaters.

\begin{abstract}
Estrogenic potencies of the effluents or water samples from wastewater treatment plants (WWTPs), industries and hospitals and some receiving rivers in Beijing city were estimated by using a human estrogen receptor recombinant yeast assay. Estrogenic activity of industrial wastewaters was found to range from 0.1 to $13.3 \mathrm{ng} \mathrm{EEQ} / \mathrm{L}$ and decreased to the range of $0.03-1.6 \mathrm{ng} \mathrm{EEQ} / \mathrm{L}$ after treatment. Estrogenic activity in WWTP influent ranged from 0.3 to $1.7 \mathrm{ng} \mathrm{EEQ} / \mathrm{L}$ and decreased to the range of $0.05-0.5 \mathrm{ng} \mathrm{EEQ} / \mathrm{L}$ after treatment. In the receiving river waters, the estrogenic effect range was $0.1-4.7 \mathrm{ng}$ EEQ/L. These data suggest that treated industrial effluents and WWTP effluents of concern are not the only source of estrogenic pollution in surface waters in Beijing city. EEQ levels in Beijing river water are likely attributable to untreated municipal and industrial wastewaters discharged directly into the river.
\end{abstract}

(C) 2006 Elsevier Ltd. All rights reserved.

Keywords: Estrogenic activity; In vitro bioassay; Wastewater treatment plant; Industrial effluent; Surface water

\section{Introduction}

Several types of adverse effects impacting the reproduction of aquatic species have been attributed to the presence of endocrine disrupters (Sumpter and Jobling, 1995). These substances have been associated with degenerative effects such as reduced fecundity, changes in sex ratio, developmental degeneration in both animal and human embryos (Bergeron et al., 1994; Blaise et al., 2003; Fry and Toone, 1981; Guillette et al., 1994, 1999; Knörr and Braunbeck, 2002), as well as an increase in breast and testis cancer in humans (Colborn et al., 1993; Giwercman et al., 1993; Shape and Skakkebaek, 1993; Toppari et al., 1996). Most of these chemicals are released into surface waters via municipal and industrial sewage treatment plant effluents. The individual compounds that are

\footnotetext{
* Corresponding author. Tel.: +86106284 9140; fax: +861062923543

E-mail address: wangzj@rcees.ac.cn (Z. Wang).
}

responsible for these harmful effects are currently unknown, but substances including nonylphenols, phthalic esters, PCBs, dioxins, phytoestrogens and human estrogens are suspected to influence the hormonal system (Roembke et al., 1996).

Although modern and powerful chemical techniques, such as gas chromatography-mass spectrometry (GC-MS), liquid chromatography-mass spectrometry (LC-MS) and liquid chromatography-nuclear magnetic resonance (LC-NMR), can detect increasing numbers of pollutants, these methods also have limitations. Instrumental analyses are expensive, and, in several cases, only a small percent of organic pollutants can be identified (Betowski et al., 1996). Furthermore, chemical analysis does not consider additive or synergistic effects of structurally different xenoestrogens present in waters, such as sewage effluent and river water samples. In contrast, bioassays can address the issues stated above (Arnold et al., 1997; Graumann et al., 1999; Islinger et al., 1999; Pawlowski et al., 2000; Smeets et al., 1999). Bioassays integrate the 
effects of all pollutants, and consider the integrated activity that may not always be additive, but can be more complicated in real life (for example, antagonistic or synergistic). As to endocrine disrupters, bioassays provide useful information that can complement instrumental analyses and a more comprehensive characterization of a sample's potential to modulate the estrogen receptor (ER) and result in estrogenic responses. Thus, bioassays can account for both unanalyzed chemicals and potential non-additive interactions among compounds.

Among the various bioassays developed to measure estrogenic activities of individual chemicals and environmental water samples (Feldman and Krishnan, 1995; Flouriot et al., 1993; Jobling et al., 1995; Pawlowski et al., 2000), the recombinant yeast assay (Arnold et al., 1997) received particular attention as a rapid and comparatively simple in vitro screening assay in laboratory and field experiments (García-Reyero et al., 2001; Harries et al., 1997; Johansson, 1999; Murk et al., 2002; Routledge and Sumpter, 1996; Soto et al., 1995).

In the present study, the yeast assay was used as a costeffective and simple in vitro screening system to detect estrogenic activity in treated and untreated effluent wastewater and river water after SPE extraction and fractionation. To this end, river water samples and effluent samples from five wastewater treatment plants, four chemical plants, three petrochemical plants, one metallurgical plant, two coke-oven plants, two hospitals, one food production plant and one pharmaceutical plant were chosen for this study. All sampling sites were located in the capital city of China, Beijing, which is one of the most highly industrialized and densely populated cities in China.

Because of the lack of information on the presence of estrogens in the Chinese aquatic environment, this study sought to obtain preliminary data of possible estrogen activity in Beijing city, which has a population of approximately 12 million inhabitants. It was felt that generating such data could prove useful to identify particular sources of endocrine disruption and to alert environmental administrators to this issue.

\section{Material and method}

A series of treated and untreated wastewater samples from different wastewater treatment plants (WWTPs), industries (chemical, petrochemical, metallurgical and coke-oven, banknote printing, meat-packing, pharmaceutical manufacturing plants) and hospitals were collected in 2003. In addition, influents and effluents from five municipal sewage treatment plants (Gaobeidian, Beixiaohe, Qinghe, Fangzhuang, Jiuxianqiao) and river water samples from four rivers that receive effluents from the five WWTPs were collected.

All the water samples $(40 \mathrm{~L})$ were taken over a period of $24 \mathrm{~h}$ during January 2003 according to a standard protocol (US EPA, 2002), and were processed immediately upon arrival in the laboratory. Water samples were filtered through $0.7-\mu \mathrm{m}$ glass fiber filters (APFF; Millipore, USA), and extracted using HLB solid phase extraction columns (6 ml, $500 \mathrm{mg}$, Oasis; Waters, USA), which had been conditioned with $5 \mathrm{ml} \mathrm{CH}_{2} \mathrm{Cl}_{2}$ (HPLC Grade; Fisher, USA), $5 \mathrm{ml}$ methanol (HPLC Grade; Fisher), as well as $5 \mathrm{ml}$ deionized water (Zhou et al., 2005). The columns were then eluted three times with $5 \mathrm{ml}$ $\mathrm{CH}_{2} \mathrm{Cl}_{2}$ and the elutions were combined followed by blowing down to $1 \mathrm{ml}$ under a nitrogen stream.

Each elution was then carefully added on a column containing $10 \mathrm{~g}$ silica (60-200 $\mu \mathrm{m}, 60 \mathrm{~A}$, ultra pure, Acros Organics) and $10 \mathrm{~g} \mathrm{Al}_{2} \mathrm{O}_{3}(50-200 \mu \mathrm{m}$, Acros Organics). The column was eluted with $15 \mathrm{ml}$ hexane (HPLC Grade; Fisher) to yield a nonpolar fraction, followed by $70 \mathrm{ml}$ mixture of hexane/
$\mathrm{CH}_{2} \mathrm{Cl}_{2}(\mathrm{v} / \mathrm{v}=7: 3)$ to obtain a polar fraction. The sub-fractions were evaporated to $2 \mathrm{ml}$ using a rotary-evaporator (Buchi Rotavapor R-200, Switzerland) followed by blowing to dryness with a gentle nitrogen flow.

The residues, including the two fractions of each sample, were dissolved in $0.5 \mathrm{ml}$ dimethyl sulfoxide (DMSO; ACS grade, Sigma Chemical Co.) and stored at $20{ }^{\circ} \mathrm{C}$ for the yeast bioassay. A procedural blank using deionized water was run alongside the samples as an assay control.

Recombinant yeast (Saccharomyces cerevisiae) cells were kindly provided by J.P. Sumpter from Brunel University, Uxbridge, UK. Yeast cells were cultured and the assay was carried out as described by Routledge and Sumpter (1996) and Wu et al. (2002) with some modifications.

Selective medium (SC medium) was prepared following the procedures of Gaido et al. (1997) and Routledge and Sumpter (1996). All chemicals have a purity of $>99.9 \%$ and none were repurified prior to use. The yeast strain was grown at $30^{\circ} \mathrm{C}, 130 \mathrm{rpm}$ overnight, in Erlenmeyer flasks using $\mathrm{CuSO}_{4}$ supplemented $\left(5 \times 10^{-8} \mathrm{M}\right) \mathrm{SC}$ medium. In performing the assay, exponentially growing overnight cultures were diluted with $\mathrm{SC}$ medium to an $\mathrm{OD}_{600 \mathrm{~nm}}$ of 0.25 .

All environmental samples were assayed with a minimum of three replicates. Each sample assayed included a positive control (17 $\beta$-estradiol) and a negative control (DMSO). The procedural blank, subjected to SPE and fractionation, was also run alongside the samples to monitor for any false positive results. The effects of estrogenic compounds were standardized against $17 \beta$ estradiol $\left(E_{2}\right)$. Each test extract was diluted in a 1:2 series in DMSO for a total of six concentrations. Serial dilutions $(5 \mu \mathrm{l})$ of test samples were combined with $995 \mu \mathrm{l}$ of medium containing $5 \times 10^{3}$ yeast cells $/ \mathrm{ml}$ resulting in a test culture in which the volume of DMSO did not exceed $0.5 \%$ of the total volume. One hundred microliters of the test cultures was transferred into each well of a 96-well plate and incubated at $30{ }^{\circ} \mathrm{C}$ with vigorous orbital shaking $(130 \mathrm{rpm})$ on a titer plate shaker (Heidolph Titramax 1000, Germany) for $2 \mathrm{~h}$ (Rehmann et al., 1999). Then the cell density of the culture was measured at $600 \mathrm{~nm}$ wavelength (Tecan GENios A-5002, Austria).

Fifty microliters of test culture was transferred to a new 96-well plate, and after the addition of $120 \mu \mathrm{l}$ of Z-buffer and $20 \mu \mathrm{l}$ chloroform, the assays were carefully mixed (vortex $25 \mathrm{~s}$ ) and preincubated for $5 \mathrm{~min}$ at $30^{\circ} \mathrm{C}$. The enzyme reaction was started by adding $40 \mu \mathrm{lo}-\mathrm{NPG}(13.3 \mathrm{mM}$, dissolved in Z-buffer). The assays were incubated at $30^{\circ} \mathrm{C}$ on a titer plate shaker. The reactions were terminated by the addition of $100 \mu \mathrm{Na}_{2} \mathrm{CO}_{3}(1 \mathrm{M})$. For $\mathrm{E}_{2}$, the incubation time lasted $20 \mathrm{~min}$ and for the samples, $60 \mathrm{~min}$. After centrifugation at $12,000 \times g$ for $15 \mathrm{~min}$ (Sigma Laborzentrifugen $2 \mathrm{~K} 15$, Germany), $200 \mu \mathrm{l}$ of the supernatant were transferred into a new 96-well plate and the $\mathrm{OD}_{420 \mathrm{~nm}}$ was determined. Data were processed as described by Wang et al. (2003), compared with $\mathrm{E}_{2}$ induction rates, and expressed as estradiol equivalents (EEQ).

\section{Results and discussion}

\subsection{Concentration-response curve for 17 $\beta$-estradiol}

In each assay, $17 \beta$-estradiol was used as a reference to produce a standard curve. Fig. 1 shows an example of the standard concentration-response relationship obtained with $17 \beta$-estradiol $\left(\mathrm{E}_{2}\right)$. The calculated $\mathrm{EC}_{50}$ of $17 \beta$-estradiol was equal to $0.32 \pm 0.08 \mathrm{ng} / \mathrm{ml}$, which is comparable to values obtained in other laboratories (Gaido et al., 1997; Rehmann et al., 1999; Wang et al., 2003).

\subsection{Industrial effluents}

Effluents from 13 different industries and some of their corresponding untreated wastewaters were evaluated by using the yeast assay (Fig. 2). Estrogenic activity was detected in all treated and untreated wastewater samples from all investigated industries. There did not appear to be a particular response 


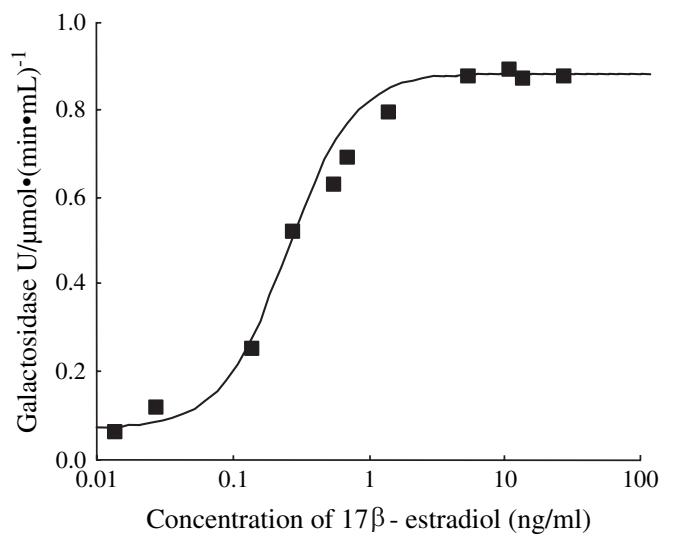

Fig. 1. The dose-response curve for $17 \beta$-estradiol.

pattern associated with either the polar or nonpolar fractions. Estrogenic activity in the untreated wastewater varied from 0.11 to $13.27 \mathrm{ng} \mathrm{EEQ} / \mathrm{L}$ in the nonpolar fraction and from 0.16 to $12.58 \mathrm{ng} \mathrm{EEQ} / \mathrm{L}$ in the polar fraction. After treatment, all effluents displayed much lower estrogenic effects with an activity range of $0.03-1.14 \mathrm{ng} \mathrm{EEQ} / \mathrm{L}$ in the nonpolar fractions and $0.05-1.63 \mathrm{ng} E E Q / L$ in the polar fractions. The marked variation in estrogenic activity response in the wastewaters was probably linked to their chemical makeup. For example, wastewater of the DOP (Dioctyl Phthalate) workshop in Beijing No. 4 chemical plant (B) showed high estrogenic activity owing to its production of DOP. Phthalates are essentially used as plasticizers in the production of polymeric materials such as polyvinyl chloride (PVC), imparting flexibility and workability, both during the manufacturing process and right up to the end product. Phthalates are just one of the many classes of chemicals that have been implicated as having estrogenic properties. Evidence of the estrogenic behavior of certain phthalates in vitro has previously been reported (Jobling et al., 1995; Sonnenschein et al., 1995; Soto et al., 1995), although their activity observed in the yeast assay was not high (Catherine et al., 1997). However, some effluents from the same type of industry displayed different estrogenic activity. For example, estrogenic activity for the nonpolar fraction in effluent from Fuxing hospital was 11 times higher than that of Beijing Union Medical College Hospital. Beijing Zizhu pharmaceutical plant, whose major products are drugs for birth control and for reproductive health, showed very low estrogenic activity in its wastewater with an EEQ of $1.91 \mathrm{ng} / \mathrm{L}$ in the nonpolar fraction and of $1.46 \mathrm{ng} / \mathrm{L}$ in the polar fraction. These variations may also be explained by the complexity of interactions among different components in the effluents, which can impart synergistic or antagonistic effects. Corroboration of this hypothesis will obviously require additional studies.

\subsection{WWTP effluents}

Gaobeidian WWTP (A), with a daily treatment capacity of 1 million cubic meters, is the largest WWTP in Beijing. It is located in the eastern part of Beijing city. Beixiaohe WWTP (B) and Qinghe WWTP (C) are located at the north part of Beijing while Fangzhuang (D) and Jiuxianqiao (E) WWTPs

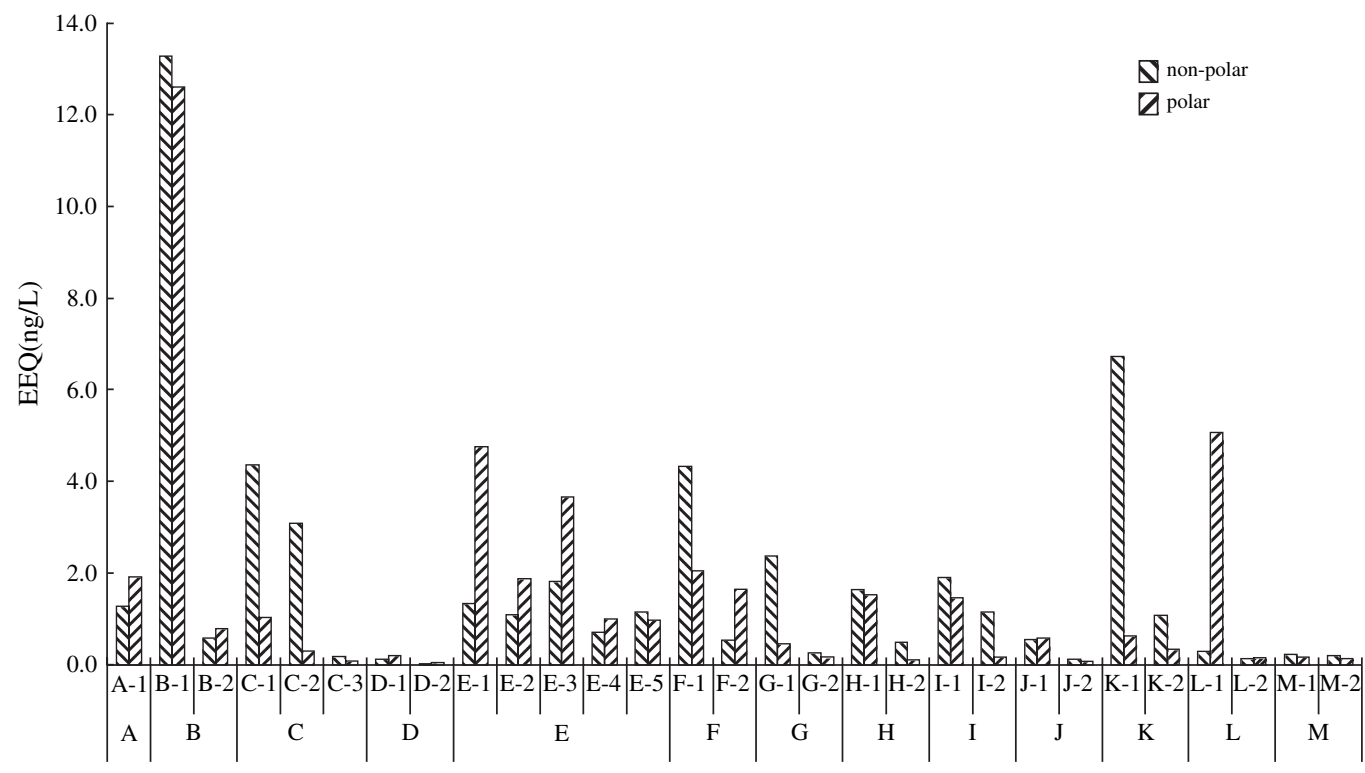

Fig. 2. The estrogenic activity of treated and untreated wastewater from different industry. A, No.2 Chemical plant; A-1, treated effluent; B, No.4 Chemical plant; B-1, DOP workshop effluent; B-2, treated effluent; C, Dongfang Chemical plant; C-1, olefin workshop effluent; C-2, acrylic acid workshop effluent; C-3, treated effluent; D, organic chemical plant; D-1, influent; D-2,treated effluent; E, Beijing Yanshan Petrochemical Co. Ltd.; E1-E3, No.1, No.2, No.3 workshop; E-4, polyester plant; E-5, treated effluents of E1-E4; F, Beijing coke-oven plant; F-1, influent; F-2, treated effluent; G, coke-oven plant of Shougang Group; G-1, influent; G-2, treated effluent; H, metallurgical plant of Shougang Group; H-1, sinter workshop effluent; H-2, treated effluent; I, Beijing Zizhu pharmaceutical plant; I-1, influent; I-2, treated effluent; J, Beijing Union Medical College Hospital; J-1, influent; J-2, treated effluent; K, Fuxing Hospital; K-1, influent; K-2, treated effluent; L, Beijing banknote plant; L-1, printing plate rubbing workshop effluent; L-2, treated effluent; M, Beijing Huadu Broiler Co.; M-1, influent; M-2, treated effluent. 
are located at the south and the northeast part of Beijing, respectively (Fig. 3).

Estrogenic activity was detected in all WWTP samples (Fig. 4). In the influent, it ranged from 0.33 to $0.95 \mathrm{ng}$ $\mathrm{EEQ} / \mathrm{L}$ for the nonpolar fraction, while the polar fraction was $0.30-1.66 \mathrm{ng} \mathrm{EEQ} / \mathrm{L}$. These values are much lower than those of some WWTPs effluents in France and Germany (Cargouët et al., 2004; Pawlowski et al., 2004). The Gaobeidian (A) effluent showed higher estrogenic effect in its nonpolar fraction than in its polar fraction, while that from Fangzhuang (D) showed the opposite. Effluents in the other three WWTPs indicated similar effects in both polar and nonpolar fractions. The largest WWTP, Gaobeidian (A), is located in eastern Beijing, which is the most industrialized area in the city. However, its influent showed lower estrogenic activity as compared to B, C, and D WWTPs. The lowest effect was observed in Jiuxianqiao (E), which is very close to the city center. After the treatment process, estrogenic activities could still be detected in effluents with the EEQ value ranging from 0.08 to $0.25 \mathrm{ng} / \mathrm{L}$ for nonpolar fractions and $0.05-0.46 \mathrm{ng} / \mathrm{L}$ for polar fractions.

Wastewater treatment plants (WWTPs) receive a large spectrum of molecules from both domestic and industrial waste, which are not totally eliminated during the treatment processes (Daughton and Ternes, 1999; Ternes et al., 1998). At the outlets of the WWTPs, a complex mixture of molecules including partially eliminated wastewater molecules, as well as metabolites formed during treatment processes, are finally discharged into the rivers. In this context, WWTP discharges are considered as a major source of estrogenic surface water pollution that may play a significant role in environmental contamination. Thus, the ability of WWTPs to remove EDCs from influents is a major concern for the water quality of the receiving river. The removal rate for nonpolar fractions in these five WWTPs are 43\%, 85\%, 87\%, 79\% and $75 \%$ for A, B, C, D, and E, respectively, while polar fractions are removed at rates corresponding to $74 \%, 85 \%, 87 \%$, $72 \%$ and $81 \%$. These values are comparable to those in the USA where removal rates ranged from $67 \%$ to $97 \%$. (Tilton et al., 2002).

\subsection{Receiving river water}

Estrogenic effects in four rivers, which receive effluents from the A, B, C, D and E WWTPs investigated in this study, were also evaluated with the yeast assay. The treated effluent of Gaobeidian WWTP (A) flows into Thonghuihe river (TH river). The treated effluents of both of Beixiaohe (B) and Jiuxianqiao (E) WWTPs flow into Bahe river (BH river), while that of Qinghe WWTP (C) to Qinghe river ( $\mathrm{QH}$ river) and Fangzhuang WWTP (D) to Liangshuihe river (LSH river) through a pipeline (Fig. 3). Effluents flowed into the corresponding rivers at positions located between the upstream sampling sites and the middle stream sampling sites of each river.

The EEQ values of river water samples and effluents of the corresponding WWTPs, which these rivers receive, together with the daily treatment capacity of the WWTPs are given in Table 1. Estrogenic activity of the nonpolar fraction of the river water ranged from 0.12 to $4.66 \mathrm{ng} \mathrm{EEQ} / \mathrm{L}$ and the range for the polar fraction was $0.07-1.09 \mathrm{ng} \mathrm{EEQ} / \mathrm{L}$. We could not find any particular relationship between the polar and nonpolar fractions for these samples. The estrogenic activities did not suggest certain variation patterns of the rivers from upstream to downstream. One exception was the Bahe river, which receives effluents from both $\mathrm{B}$ and $\mathrm{E}$, showing the highest estrogenic activity in both of the polar (1.09 ng $\mathrm{EEQ} / \mathrm{L}$ ) and nonpolar (4.66 ng EEQ/L) fractions upstream, with gradual decreases from midstream to downstream. This result suggested the occurrence of an upstream source of estrogen pollutants in this river where they deposit in the sediment during the flow. For all data of the four river water samples, the EEQ values were, in general, higher than those of the corresponding effluents. This suggests that estrogenic effects detected in these rivers do not result from WWTP effluents but from other sources of estrogenic pollution along the rivers.

The aim of this study sought to evaluate the estrogenic contamination of rivers in the Beijing area and the corresponding contribution of WWTPs and industry effluents. By using a recombinant yeast assay, the estrogenic activity in industrial wastewaters and their effluents after treatment as well as in

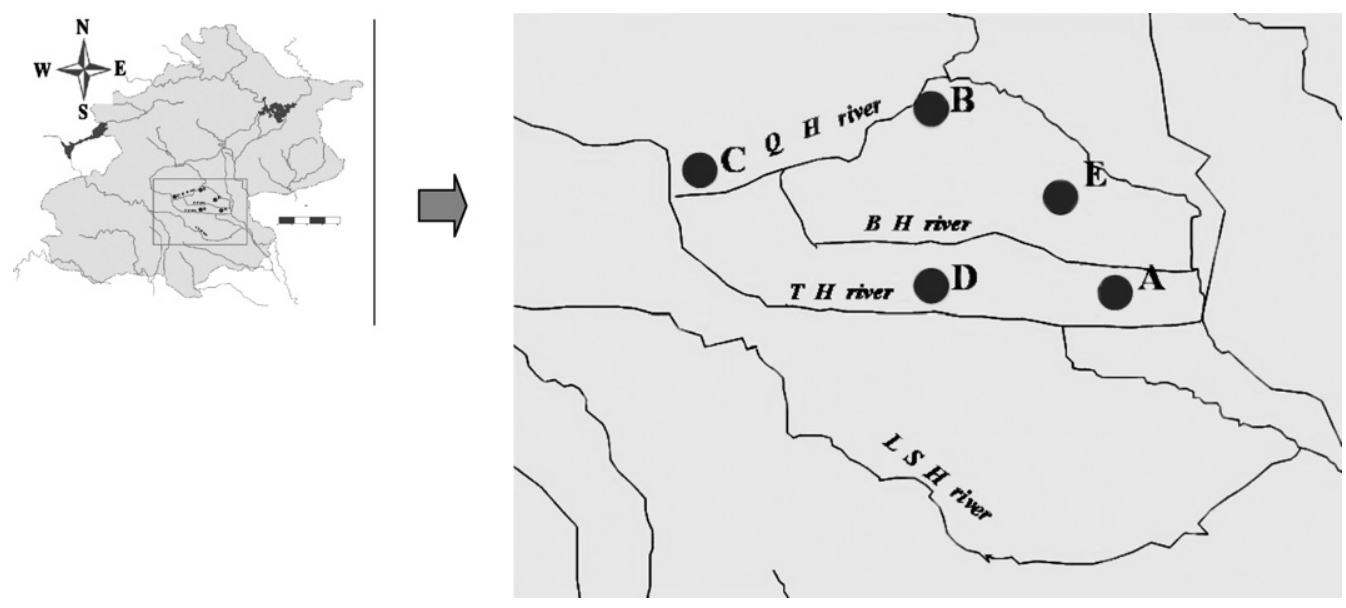

Fig. 3. Location of the WWTPs and the rivers. 


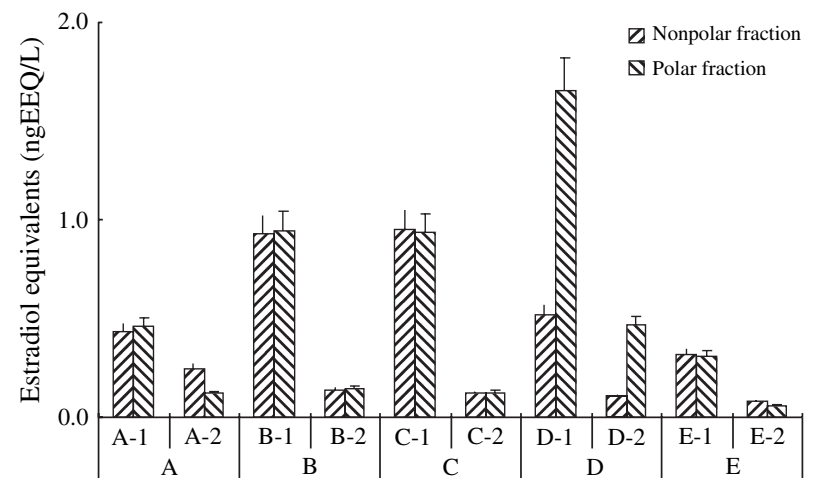

Fig. 4. Estrogenic effects for effluents before and after treatment in different municipal sewage treatment plants by using the yeast estrogen screen. A, Gaobeidian; B, Beixiaohe; C, Qinghe; D, Fangzhuang; E, Jiuxianqiao. 1 and 2 represent influent and effluent, respectively.

effluents of different WWTPs and in surface waters could be clearly detected. In Beijing city, the estrogenic activity of nonpolar fractions in industrial wastewater ranged from 0.11 to $13.27 \mathrm{ng} \mathrm{EEQ} / \mathrm{L}$ and that of polar fractions from 0.16 to $12.58 \mathrm{ng} \mathrm{EEQ} / \mathrm{L}$. After treatment, the estrogenic activity of nonpolar and polar fractions decreased to a range of 0.03 to $1.14 \mathrm{ng}$ EEQ/L and 0.05 to $1.63 \mathrm{ng} \mathrm{EEQ} / \mathrm{L}$, respectively. The estrogenic activity in WWTP effluent ranged from 0.08 to $0.25 \mathrm{ng} \mathrm{EEQ} / \mathrm{L}$ for nonpolar fractions and from 0.05 to $0.46 \mathrm{ng} \mathrm{EEQ} / \mathrm{L}$ for polar fractions. Estrogenic activity in industrial effluent and WWTPs effluents was not, as expected, higher than those in surface water, whose nonpolar fraction estrogenic activity ranged from 0.12 to $4.66 \mathrm{ngEEQ} / \mathrm{L}$ and polar fraction from 0.07 to $1.09 \mathrm{ngEEQ} / \mathrm{L}$. This indicated that industrial effluents were not the major contributors to estrogenic pollution in Beijing city.

An important source of estrogenic activity in surface water is that from industrial and municipal wastewaters without

Table 1

EEQ values of river water samples and effluents of the corresponding WWTPs that these rivers receive (ng EEQ/L)

\begin{tabular}{|c|c|c|c|c|c|}
\hline \multirow{2}{*}{$\begin{array}{l}\text { WWTPs and } \\
\text { their daily } \\
\text { treatment } \\
\text { capacity } \\
\left(\text { in million } \mathrm{m}^{3} \text { ) }\right.\end{array}$} & \multicolumn{2}{|c|}{$\begin{array}{l}\text { Estrogenic activity } \\
\text { of the effluents } \\
\text { (ng EEQ/L) }\end{array}$} & \multirow[t]{2}{*}{$\begin{array}{l}\text { Sampling } \\
\text { sites on } \\
\text { the rivers }\end{array}$} & \multicolumn{2}{|c|}{$\begin{array}{l}\text { Estrogenic activity } \\
\text { of the river water } \\
(\text { ng EEQ/L) }\end{array}$} \\
\hline & $\begin{array}{l}\text { Nonpolar } \\
\text { fraction }\end{array}$ & $\begin{array}{l}\text { Polar } \\
\text { fraction }\end{array}$ & & $\begin{array}{l}\text { Nonpolar } \\
\text { fraction }\end{array}$ & $\begin{array}{l}\text { Polar } \\
\text { fraction }\end{array}$ \\
\hline \multirow[t]{3}{*}{ A (1) } & \multirow[t]{3}{*}{0.25} & \multirow[t]{3}{*}{0.12} & $\mathrm{TH}$ river- $\mathrm{U}^{\mathrm{a}}$ & 0.18 & 0.15 \\
\hline & & & TH river- $\mathrm{M}^{\mathrm{b}}$ & 0.16 & 0.17 \\
\hline & & & $\mathrm{TH}$ river- $\mathrm{D}^{\mathrm{c}}$ & 0.12 & 0.17 \\
\hline B (0.04) and & 0.14 (B) & 0.14 (B) & $\mathrm{BH}$ river- $\mathrm{U}^{\mathrm{a}}$ & 4.66 & 1.09 \\
\hline \multirow[t]{2}{*}{$\mathrm{E}(0.2)$} & \multirow[t]{2}{*}{$0.08(\mathrm{E})$} & \multirow[t]{2}{*}{$0.06(\mathrm{E})$} & $\mathrm{BH}$ river- $\mathrm{M}^{\mathrm{b}}$ & 0.82 & 0.28 \\
\hline & & & $\mathrm{BH}$ river- $\mathrm{D}^{\mathrm{c}}$ & 0.32 & 0.07 \\
\hline \multirow[t]{3}{*}{$\mathrm{C}(0.2)$} & \multirow[t]{3}{*}{0.12} & \multirow[t]{3}{*}{0.12} & $\mathrm{QH}$ river- $\mathrm{U}^{\mathrm{a}}$ & 0.92 & 0.08 \\
\hline & & & $\mathrm{QH}$ river- $\mathrm{M}^{\mathrm{b}}$ & 0.44 & 0.29 \\
\hline & & & $\mathrm{QH}$ river- $\mathrm{D}^{\mathrm{c}}$ & 0.66 & 0.28 \\
\hline \multirow[t]{3}{*}{ D (0.04) } & \multirow[t]{3}{*}{0.11} & \multirow[t]{3}{*}{0.47} & $\mathrm{LSH}$ river- $\mathrm{U}^{\mathrm{a}}$ & 0.12 & 0.36 \\
\hline & & & LSH river-M $\mathrm{M}^{\mathrm{b}}$ & 0.80 & 0.14 \\
\hline & & & LSH river- $\mathrm{D}^{\mathrm{c}}$ & 0.36 & 0.17 \\
\hline
\end{tabular}

\footnotetext{
${ }^{\mathrm{a}} \mathrm{U}$ represents upstream.

${ }^{\mathrm{b}} \mathrm{M}$ represents midstream.

c D represents downstream.
}

treatment before their discharge into surface waters. In Beijing, only $50 \%$ of wastewater can be treated before discharging. As Beijing is a densely populated city, estrogenic effects detected in surface water are probably closely related to the domestic activities of urban dwellers. In fact, estrogenic pharmaceuticals are commonly prescribed principally for birth control and estrogen replacement therapy. Among them, the synthetic estrogen ethinylestradiol $\left(\mathrm{EE}_{2}\right)$, mestranol or the estradiol valerate are widely used. These compounds, in addition to natural hormones, $17 \beta$-estrodiol $\left(\mathrm{E}_{2}\right)$, estrone $\left(\mathrm{E}_{1}\right)$ and estriol $\left(\mathrm{E}_{3}\right)$, are excreted by women and consequently found in wastewater (Aherne and Briggs, 1989; Lee and Peart, 1998). Men also excrete estrogens but in lesser quantities (Fotsis and Adlercreutz, 1987). Another potential source of estrogenic activity in river water stems from pesticides used in agriculture. Pesticide formulations can contain nonylphenol polyethoxylates as spreading or wetting agents. These compounds will break down after application to produce nonylphenol. Nonylphenol was shown to produce estrogenic activity in vitro in the yeast screen (Routledge and Sumpter, 1996).

In order to link observed estrogenic activity with actual substances causing these responses, extensive chemical analysis together with Toxicity Identification Evaluation (TIE) schemes will be required. Further studies are planned in this respect.

\section{Acknowledgments}

This work was supported by the Natural Science Foundation of China (20237010), the Natural Science Foundation of Beijing (8052018) and the Natural Science Foundation of China (50378089).

\section{References}

Aherne, G.W., Briggs, R., 1989. The relevance of the presence of certain synthetic steroids in the aquatic environment. Journal of Pharmacy and Pharmacology 41, 735-736.

Arnold, S.F., Bergeron, J.M., Tran, D.Q., Collins, B.M., Vonier, P.M., Crews, D., Toscano Jr., W.A., McLachlan, J.A., 1997. Synergistic responses of steroidal estrogens in vitro (yeast) and in vivo (turtels). Biochemical and Biophysical Research Communications 235, 336-342.

Bergeron, J.M., Crews, D., McLachlan, J.A., 1994. PCBs as environmental estrogens: turtle sex determination as a biomarker of environmental contamination. Environmental Health Perspectives 102, 780-781.

Betowski, L.D., Kendall, D.S., Pace, C.M., Donnelly, J.R., 1996. Characterization of groundwater samples from superfund sites by gas chromatography/ mass spectrometry and liquid chromatography/mass spectrometry. Environmental Science and Technology 30, 3558.

Blaise, C., Gagné, F., Salazar, M., Salazar, S., Trottier, S., Hansen, P.-D., 2003. Experimentally-induced feminisation of freshwater mussels after longterm exposure to a municipal effluent. Fresenius Environmental Bulletin $12,865-870$.

Cargouët, M., Perdiz, D., Mouatassim-Souali, A., Tamisier-Karolak, S., Levi, Y., 2004. Assessment of river contamination by estrogenic compounds in Paris area (France). Science of the Total Environment 324 (1-3), 55-66.

Catherine, A.H., Henttu, P., Parker, M.G., Sumpter, J.P., 1997. The estrogenic activity of phthalate esters in vitro. Environmental Health Perspectives 105 (8), 802-811. 
Colborn, T., vom Saal, F.S., Soto, A.M., 1993. Developmental effects of endocrine disrupting chemicals in wildlife and humans. Environmental Health Perspectives 101, 378-384.

Daughton, C.G., Ternes, T.A., 1999. Pharmaceuticals and personal care products: agents for subtle change? Environmental Health Perspectives 107 (6), 907-942.

Feldman, D., Krishnan, A., 1995. Estrogens in unexpected places: possible implications for researchers and consumers. Environmental Health Perspectives 103, 129-133.

Flouriot, G., Vaillant, C., Salbert, G., Pelissero, C., Guiraud, J.M., Valotaire, Y., 1993. Monolayer and aggregate cultures of rainbow trout hepatocytes: long-term and stable liver-specific expression in aggregates. Journal of Cell Science 105, 407-416.

Fotsis, T., Adlercreutz, H., 1987. The multicomponent analysis of estrogens in urine by ion exchange chromatography and GC-MS-I. Quantitation of estrogens after initial hydrolysis of conjugates. Journal of Steroid Biochemistry $28,203-213$.

Fry, D.M., Toone, C.K., 1981. DDT-induced feminization of gull embryos. Science 213, 922-924.

Gaido, K.W., Leonard, L.S., Lovell, S., Gould, C.J., Babai, D., Portier, C.J., McDonnell, D.P., 1997. Evaluation of chemicals with endocrine modulating activity in a yeast-based steroid hormone receptor gene transcription assay. Toxicology and Applied Pharmacology 143, 205-212.

García-Reyero, N., Grau, E., Castillo, M., LÓpez De Alda, M.J., BarcelÓ, D., Pína, B., 2001. Monitoring of endocrine disruptors in surface waters by the yeast recombinant assay. Environmental Toxicology and Chemistry 20, $1152-1158$.

Giwercman, A., Carlsen, E., Keiding, N., Skakkebaek, N.E., 1993. Evidence for increasing incidence of abnormalities of the human testis: a review. Environmental Health Perspectives 101, 65-72.

Graumann, K., Breithofer, A., Jungbauer, A., 1999. Monitoring of estrogen mimics by a recombinant yeast assay: synergy between natural and synthetic compounds? The Science of The Total Environment 225, 69-79.

Guillette Jr., L.J., Gross, T.S., Masson, G.R., Matter, J.M., Percival, H.P., Woodward, A.R., 1994. Developmental abnormalities of the gonad and abnormal sex hormone concentrations in juvenile alligators from contaminated and control lakes in Florida. Environmental Health Perspectives 102, 680-688.

Guillette Jr., L.J., Woodward, A.R., Crain, D.A., Pickford, D.B., Rooney, A.A., Percival, H.F., 1999. Plasma steroid concentrations and male phallus size in juvenile alligators from seven Florida lakes. General and Comparative Endocrinology 116, 356-372.

Harries, C.A., Henttu, P., Parker, M.G., Sumpter, J.P., 1997. The estrogenic activity of phthalate esters in vitro. Environmental Health Perspectives 105, 802-811.

Islinger, M., Pawlowski, S., Hollert, H., Völkl, A., Braunbeck, T., 1999. Measurement of vitellogenin-mRNA in primary cultures of rainbow trout hepatocytes in a non-radioactive dot blot/RNAse protection assay. The Science of the Total Environment 233, 109-122.

Jobling, S., Reynolds, T., White, R., Parker, M.G., Sumpter, J.P., 1995. A variety of environmental persistent chemicals, including some phthalate plasticizers are weakly estrogenic. Environmental Health Perspectives 103, 582-587.

Johansson, E., 1999. In vitro assays for detection of endocrine disrupting compounds: estrogenic activity in recombinant yeast cells and aromatase inhibition in chicken embryo ovaries. MSc thesis, University of Uppsala.

Knörr, S., Braunbeck, T., 2002. Decline in reproductive success, sex reversal, and developmental alterations in Japanese Medaka (Oryzias latipes) after continuous exposure to octylphenol. Ecotoxicology and Environmental Safety $51,187-196$.

Lee, H.B., Peart, T.E., 1998. Determination of 17 beta-estradiol and its metabolites in sewage effluent by solid-phase extraction and Gaz chromatography/mass spectrometry. Journal of AOAC International 81, 1209-1215.
Pawlowski, S., Islinger, M., Hollert, H., Sägesser, M., Ochsenbein, U., Braunbeck, T., 2000. Endocrine activity in municipal waste water effluent samples of Switzerland assessed by vitellogenin-mRNA induction in isolated hepatocytes from male rainbow trout (Oncorhynchus mykiss). In: Third SETAC World Conference, 21-25 May, 2000, Brighton, UK.

Pawlowski, S., Ternes, T.A., Bonerz, M., Rastall, A.C., Erdinger, L., Braunbeck, T., 2004. Estrogenicity of solid phase-extracted water samples from two municipal sewage treatment plant effluents and river Rhine water using the yeast estrogen screen. Toxicology in Vitro 18, 129-138.

Rehmann, K., Schramm, K., Kettrup, A., 1999. Applicability of a yeast oestrogen screen for the detection of oestrogen-like activities in environmental samples. Chemosphere 38, 3303-3312.

Roembke, J., Knacker, T.H., Stahlschmidt-Allner, P., 1996. Studie über Umweltprobleme im Zusammenhang mit Arzneimitteln. [Study about environmental problems in context with drugs.] F+E Vorhabens Nr. 10604121 Umweltbundesamt Berlin. German Report of the Research and Development Project no 10604121 of Federal Ministry of Research and Development, Berlin, Germany.

Routledge, E.J., Sumpter, J.P., 1996. Estrogenic activity of surfactants and some of their degradation products assessed using a recombinant yeast screen. Environmental Toxicology and Chemistry 15, 241-248.

Shape, R.M., Skakkebaek, N.E., 1993. Are estrogens involved in falling sperm counts and disorders of the male reproductive tract? Lancet 341, $1392-1395$.

Smeets, J.M.W., van Holsteijn, I., Giesy, J.P., Seinen, W., van den Berg, M., 1999. Estrogenic potencies of several environmental pollutants, as determined by vitellogenin induction in a carp hepatocyte assay. Toxicological Sciences 50, 206-213.

Sonnenschein, C., Soto, A.M., Fernandez, M.F., Olea, N., Serrano, F.O., RuizLopez, M.D., 1995. Development of a marker of estrogenic exposure in human serum. Clin. Chem. 41 (12), 1888-1895.

Soto, A.M., Sonnenschein, C., Chung, K.L., Fernandez, M.F., Olea, N., OleaSerrano, F., 1995. The E-SCREEN assay as a tool to identify estrogens: an update on estrogenic environmental pollutants. Environmental Health Perspectives 103, 113-122.

Sumpter, J.P., Jobling, S., 1995. Vitellogenin as a biomarker of exposure to oestrogens. Environmental Health Perspectives 103 (S7), 173-178.

Ternes, T.A., Stumpf, M., Schuppert, B., Haberer, K., 1998. Simultaneous determination of antiseptics and acidic drugs in sewage and river water. Vom Wasser 90, 295-309.

Tilton, F., Benson, W.H., Schlenk, D., 2002. Evaluation of estrogenic activity from a municipal wastewater treatment plant with predominantly domestic input. Aquatic Toxicology 61, 211-224.

Toppari, J., Larsen, J.C., Christiansen, P., Giwercman, A., Grandjean, P., Guillette Jr., L.J., Jégou, B., Jensen, T.K., Jouannet, P., Keiding, N., Leffers, H., McLachlan, J.A., Meyer, O., Müller, J., Rajpert-de Meyts, E., Scheike, T., Sharpe, R., Sumpter, J., Skakkebaek, N.E., 1996. Male reproductive health and environmental xenooestrogens. Environmental Health Perspectives 104 (Suppl.), 741-803.

US EPA, 2002. Short-term method for estimating the chromic toxicity of effluents and receiving waters to freshwater organisms, Fourth ed. October.

Wang, J.X., Wu, W.Z., Henkelmann, B., You, L., Kettrup, A., Schramm, K.W., 2003. Presence of estrogenic activity from emission of fossil fuel combustion as detected by a recombinant yeast bioassay. Atmospheric Environment 37, 3225-3235.

Wu, W.Z., Chen, J., Rehmann, K., Schramm, K.-W., Kettrup, A., 2002. Estrogenic effects from household stoves. Ecotoxicology and Environmental Safety 53, 65-69.

Zhou, Y.Q., Xu, Y.P., Ma, M., Wang, Z.J., 2005. Simultaneous determination of nonylphenols and phthalates in water by pre-column derivatization and gas chromatography coupled with mass spectrum. Journal of Instrumental Analysis 2, 49-52. 